\title{
AGRO-ECONOMIC PERFORMANCE OF INTERCROPPING HYBRID MAIZE WITH VEGETABLES AND SPICES AT FARMER'S FIELD
}

\author{
M. I. Nazrul \\ Senior Scientific Officer, On-Farm Research Division, Bangladesh Agricultural Research Institute (BARI) \\ Corresponding author, Email: mi_nazrul@yahoo.com; m.i.nazrul@gmail.com
}

(Received: 4 December 2018, Accepted: 9 April 2019)

Keywords: intercropping, maize, vegetables, spices, yield, cost-benefit

\begin{abstract}
The experiment was conducted at Multi Location Testing (MLT) site, Moulvibazar, Bangladesh during rabi season of 2016-17 and 2017-18 to study the profitability of intercropping of hybrid maize with vegetables and spices. Five intercrop combinations of hybrid maize along with sole maize were arranged in randomized complete block design (RCBD) replicated six times. There were six treatments viz., $\mathrm{T}_{1}$ : Maize + potato, $\mathrm{T}_{2}$ : Maize + red amaranth, $\mathrm{T}_{3}:$ Maize + spinach, $\mathrm{T}_{4}$ : Maize+ data shak, $\mathrm{T}_{5}$ : Maize + coriander and $\mathrm{T}_{6}$ : Maize as sole. The grain yield of maize in intercropped combination varied significantly. The highest grain yield $\left(9.71 \mathrm{t} \mathrm{ha}^{-1}\right)$ was in sole maize. The highest maize equivalent yield 15.60 $\mathrm{t} \mathrm{ha}^{-1}$ was recorded from the treatment $\mathrm{T}_{1}(100 \%$ maize + potato) whereas the lowest yield $\left(8.61 \mathrm{t} \mathrm{ha}^{-1}\right)$ was obtained from the treatment $\mathrm{T}_{6}$ (sole maize). The highest gross return (Tk. $312000 \mathrm{ha}^{-1}$ ) and benefit cost ratio (3.29) was obtained from the treatment $\mathrm{T}_{1}(100 \%$ maize + potato). On the contrary, the lowest gross margin (Tk. 101600 ha $^{-1}$ ) was obtained from treatment $\mathrm{T}_{2}$ (maize + red amaranth). It revealed that the combination of maize with potato was more compatible and profitable intercropping system in Sylhet region of Bangladesh.
\end{abstract}

\section{Introduction}

Maize is a very common, popular and multi uses cereal crop at present situation over the world. Every year a huge amount of maize grain is required as feed and fodder for poultry and livestock sector and most of them are imported (Pandey and Koirala. 2017). Maize can be used as alternative crop of rice or wheat to fulfill the food demand for the increasing population in our country. The climate of Bangladesh is suitable for maize cultivation. Popularity of maize cultivation is increasing day by day of our country. It is generally grown in our country during winter season. Most of the farmers grow maize as a sole crop in this region but maize is a long duration crop. In that case, farmers can easily cultivate different short duration vegetables and spice crops with maize in existing cropping pattern. Intercropping has already recognized as a potentially beneficial system of crop production. It is traditional practice in Bangladesh. It increases (Marshal and willey, 1983; Quayum et al., 1999; Caruford, 2000) total productivity by judicious choice of compatible crops, by adopting appropriate planting geometry, inter/intra specific competition may be minimized resulted efficient use of natural resources. Through intercropping system the total crop production and income of per unit area will be increased (Akanda and Quayyum, 1982; Shaheb and Nazrul, 2014). Intercropping can play an important role in increasing vegetable production (Rashid, 1987). So, suitable crop combinations need to be identified through better compatibility. Besides, intercropping increased total production (Rahman, 1999 and Mondol et al., 1999) and greater profit 
margin and utilize higher resource use efficiency (Hashem and Moniruzzaman, 1986). Hence, the present experiment was conducted to increase yield and economic return of farmers and improve the productivity of existing cropping pattern as well as land bring under cultivation by intercropping practices in Sylhet region.

\section{Materials and Methods}

The experiment was conducted at Multi Location Testing (MLT) site, Moulvibazar during rabi season of 2016-17 and 2017-18 to study the feasibility of intercropping of hybrid maize with different short duration vegetables and spices and economic returns. Five intercrop combinations of hybrid maize along with sole maize were arranged in randomized complete block design replicated six times. There were six treatments viz., $\mathrm{T}_{1}$ : Maize + potato, $\mathrm{T}_{2}$ : Maize + red amaranth, $\mathrm{T}_{3}$ : Maize + spinach, $\mathrm{T}_{4}$ : Maize + data shak, $\mathrm{T}_{5}:$ Maize + coriander and $\mathrm{T}_{6}$ : Maize as sole. The unit plot size was $8 \mathrm{~m} 45 \mathrm{~m}$. Hybrid maize (var. BARI Hybrid Maize-9). Potato (var. Diamant), Spinach (var. Local), Red amaranth (var. BARI Lalshak-1), and coriander (var. local) were used as component crops. The seeds of maize, potato, spinach, red amaranth, data shak, and coriander were sown during 25-28 November in each year with maintaining recommended methods. The spacing for sole and intercropping maize was $60 \mathrm{~cm} \times 25 \mathrm{~cm}$. Fertilizers were applied @ 255-55-1-40-40-6-2 kg ha ${ }^{-1}$ N-P-K-Zn-B for maize. One-third $\mathrm{N}$ and full amount of all other fertilizer were applied as basal. Rest $\mathrm{N}$ was applied as top dress in two equal splits at 30 and 60 days after sowing (DAS). Subsequently three irrigations were applied at 20, 30 and 60 DAS. Ear thing up was done at 30 days after planting potato. Two hand weeding were done at 20 and 25 DAS to keep the crop reasonably weed free. The component crops were harvested 10-20 February and maize harvested from 1012 May, 2016-17 and 2017-18. ; Ten maize plants were randomly selected prior to harvest from each plot; yields of companion were collected from whole plot basis. At harvest, the yield data was recorded plot wise and analyzed statistically and mean separations were done by LSD using statistical tools for agricultural research (STAR) package. Maize equivalent yield (MEY) and benefit cost analysis also done.

Grain yield of maize was determined at $14 \%$ moisture content. Equivalent yield of component crops were determined following the method of Anjaneyulu et al. (1982). Maize Equivalent

Yield $(\mathrm{MEY})=\mathrm{Ym}+(\mathrm{Yi} \mathrm{Y} \mathrm{Pi}) / \mathrm{Pm}$

Where, $\mathrm{Ym}=$ Yield of maize $\left(\mathrm{t} \mathrm{ha}^{-1}\right)$

$\mathrm{Yi}=$ Yield of intercrop vegetable $\left(\mathrm{t} \mathrm{ha}^{-1}\right)$

$\mathrm{Pi}=$ Price of intercrop vegetables $\left(\mathrm{Tk} \mathrm{ha}^{-1}\right)$

$\mathrm{Pm}=$ Price of maize $\left(\mathrm{Tk} \mathrm{ha}{ }^{-1}\right)$

The relative yield was obtained by dividing the intercrop yield of a crop with the respective sole crop yield of that crop using the formula (Dewit and Vander Bergh, 1965).

$$
\text { The relative yield of crops }=\frac{\text { Yield of components crops }}{\text { Yield of sole crops }}
$$




\section{Effect on yield and yield components of maize}

Pooled analysis was done as there was no difference in characters in years. Among the yield and yield contributing characters of intercropped maize cob length and stover yields were not statistically significant (Table 1). However, agronomic performance of sole maize was a little bit higher than the treatments. The highest grain yield $\left(9.71 \mathrm{t} \mathrm{ha}^{-1}\right)$ was recorded from sole maize that was statistically similar with $\mathrm{T}_{4}$ (maize + data shak) and $\mathrm{T}_{1}$ (maize + potato) and $\mathrm{T}_{5}$ (maize + coriander), which could be due to higher weight of cobs, no. of grains/cob and 1000-grain weight. On the other hand, the lowest grain yield $7.17 \mathrm{t} \mathrm{ha}^{-1}$ was recorded from $\mathrm{T}_{3}$ (maize + spinach). The yield data indicated that there was not significant yield loss of maize due to intercropped with potato, data shak and coriander.

Table 1. Yield and yield contributing characters of maize under different intercropping situation at Moulvibazar

\begin{tabular}{|c|c|c|c|c|c|c|c|}
\hline Crop combinations & $\begin{array}{c}\text { Plant } \\
\text { height } \\
(\mathrm{cm})\end{array}$ & $\begin{array}{c}\text { Cob } \\
\text { length } \\
\text { (cm) }\end{array}$ & $\begin{array}{c}\text { Weight } \\
\text { of cob } \\
\text { (g) }\end{array}$ & $\begin{array}{c}\text { Grains } \\
\mathrm{cob}^{-1}\end{array}$ & $\begin{array}{c}1000 \\
\text { grain } \\
\text { wt. (g) }\end{array}$ & $\begin{array}{l}\text { Grain } \\
\text { yield } \\
\left(\mathrm{t} \mathrm{ha}^{-1}\right)\end{array}$ & $\begin{array}{c}\text { Stover } \\
\text { yield } \\
(\mathrm{t} \text { ha } \\
1\end{array}$ \\
\hline $\mathrm{T}_{1}$ :Maize + Potato & 194.00 & 13.70 & 103.13 & 151.83 & 353.33 & 9.60 & 11.86 \\
\hline $\begin{array}{l}\mathrm{T}_{2} \text { :Maize + Red } \\
\text { mamanth }\end{array}$ & 151.63 & 13.60 & 118.67 & 191 & 214.67 & 7.20 & 10.94 \\
\hline $\mathrm{T}_{3}:$ Maize + Spinach & 195.40 & 15.97 & 114.33 & 210.03 & 230.67 & 7.17 & 11.12 \\
\hline $\begin{array}{l}\mathrm{T}_{4} \text { :Maize + Data } \\
\text { Shak }\end{array}$ & 182.93 & 15.00 & 00 & 209.63 & 358.00 & 9.70 & 11.93 \\
\hline $\begin{array}{l}\mathrm{T}_{5} \text { :Maize + } \\
\text { Coriander }\end{array}$ & 203.83 & 15.00 & 129.50 & 208.87 & 291.00 & 9.39 & 11.50 \\
\hline T:Maize as sole & 203.83 & 14.33 & 134.37 & 240.80 & 382.00 & 9.71 & 11.84 \\
\hline CV (\%) & 2.93 & 10.44 & 6.4 & 11 & 7.7 & 4.51 & 3.91 \\
\hline LSD & 15.67 & NS & 21.57 & 63.49 & 69.06 & 1.13 & NS \\
\hline
\end{tabular}

\section{Effect of intercrops}

The intercrop yield of potato, red amaranth, spinach, data shak and coriander were influenced significantly by different intercropping combinations (Table 2). The maximum yield of component crops (potato) was recorded from maize + potato intercropping combination followed by spinach combination. The lowest yield was obtained from maize + coriander intercropping combination.

\section{Relative yield}

Relative yield determines competitive ability of component crops in intercropping system. Greater value of relative yield showed more competitive ability in intercrop situation compared to its monoculture (Juskiw et al., 2000). The relative yields of maize were $0.99,0.74,0.750 .99$ and 0.97 when maize was intercropped with potato, red amaranth, spinach, data shak and coriander, respectively (Table 2). This indicates that maize yield was reduced by $1 \%, 26 \%$, $25 \%, 1 \%$, and $3 \%$ of sole crop when it was intercropped with potato, red amaranth, spinach, data shak and coriander, respectively. The lower relative yield of maize in intercropping indicated that the crop faced competition for space, nutrients, light, and water with component crops. The findings are in agreement with that of Singh (1993) and Rahman (1999).

\section{Maize equivalent yield}

All the intercropped combinations showed higher maize equivalent yield than sole maize in all cases. Among the treatments, significantly the highest maize equivalent yield $(15.60 \mathrm{t} \mathrm{ha-1})$ was obtained from maize + potato intercrop 
combination (Table 2). Though highest grain yield was recorded from sole maize but equivalent yield and economic return was much lower than other treatment. Similar results were observed by researchers Rahaman, et al., 2015 and Hossain, et al., 2015. The lowest maize equivalent yield $\left(9.53 \mathrm{t} \mathrm{ha}^{-1}\right)$ was obtained from maize + red amaranth intercrop combination. Although maize yield was $1 \%$, $26 \%, 25 \%, 1 \%$, and 3\% lower than sole crop when it was intercropped with when it was intercropped with potato, red amaranth, spinach, data shak and coriander. But maize equivalent yield from maize + potato, maize + red amaranth, maize + spinach, maize + data shak and maize + coriander intercrop combination showed 81\%, 11\%, 14\%, 52\% and 51\% higher yield advantage over the sole maize, respectively. Sarker et al. (2013) reported that the lowest maize equivalent yield, gross margin and benefit cost ratio were obtained from sole crop of maize. This result showed that maize + potato was the best intercrop combination in respect of total yield advantage followed by maize + data shak and maize + coriander inter cropping system.

Table 2. Grain yield of sole maize, intercrop yield, relative yield and equivalent yield of maize as influenced by intercropping with vegetables and spices at Moulvibazar.

\begin{tabular}{|c|c|c|c|c|}
\hline Crop combinations & $\begin{array}{l}\text { Grain } \\
\text { yield } \\
\left(\mathrm{t} \mathrm{ha}^{-1}\right) \\
\end{array}$ & $\begin{array}{c}\text { Intercrop } \\
\text { yield } \\
\left(\mathrm{t} \mathrm{ha}{ }^{-1}\right)\end{array}$ & $\begin{array}{c}\text { Relative yield } \\
\text { of } \\
\text { Maize } \\
\end{array}$ & $\begin{array}{c}\text { Maize } \\
\text { equivalent } \\
\left.\text { yield ( } \mathrm{t} \mathrm{ha} \mathrm{a}^{-1}\right)\end{array}$ \\
\hline $\mathrm{T}_{1}$ :Maize + Potato & 9.60 & 10.00 & 0.99 & 15.60 \\
\hline $\begin{array}{l}\mathrm{T}_{2} \text { :Maize +Red } \\
\text { amaranth }\end{array}$ & 7.20 & 5.83 & 0.74 & 9.53 \\
\hline $\mathrm{T}_{3}:$ Maize + Spinach & 7.17 & 6.78 & 0.75 & 9.88 \\
\hline $\mathrm{T}_{4}$ :Maize + Data Shak & 9.70 & 5.69 & 0.99 & 13.11 \\
\hline $\mathrm{T}_{5}$ :Maize + Coriander & 9.39 & 2.95 & 0.97 & 13.08 \\
\hline $\mathrm{T}_{6}$ :Maize as sole & 9.71 & 0.00 & 1.00 & 8.61 \\
\hline CV (\%) & 4.51 & $=$ & - & - \\
\hline $\operatorname{LSD}_{(0.05)}$ & 1.13 & $=$ & - & - \\
\hline
\end{tabular}

\section{Monetary advantage}

An analysis on cost and return of intercropping maize with different short duration components crops have been presented in Table 3. Higher gross return was obtained from all intercrop combinations than sole crop. Many researchers also documented higher gross margin or net return in intercropping system than sole crop (Ali, et al., 2015; Alam et al., 2008; Bhuiyan et al., 2013; Farhad et al., 2014; Rahaman, et al., 2015 and Hossain, et al., 2015). Among the combinations, the highest gross return was obtained from maize + potato intercropping system, which was $81 \%$ higher than sole maize. Almost similar trend was followed in case of gross margin. The higher benefit-cost ratio (BCR) was recorded from maize + garden pea combination followed by maize + bush bean.

Table 3. Monetary advantage analysis of maize intercropping with vegetables and spices at Moulvibazar (average of 2 years)

\begin{tabular}{|c|c|c|c|c|c|}
\hline Crop combinations & $\begin{array}{c}\text { Maize } \\
\text { equivalent } \\
\text { yields (t ha- } \\
1 \text { ) }\end{array}$ & $\begin{array}{c}\text { Gross } \\
\text { return } \\
(\text { Tk. ha-1) }\end{array}$ & $\begin{array}{c}\text { Total } \\
\text { variable cost } \\
\left(\text { Tk. ha }{ }^{-1}\right)\end{array}$ & $\begin{array}{c}\text { Gross } \\
\text { margin } \\
(\text { Tk. ha-1) }\end{array}$ & $\begin{array}{l}\text { Benefit } \\
\text { cost } \\
\text { ratio }\end{array}$ \\
\hline $\mathrm{T}_{1}$ :Maize + Potato & 15.60 & 312000 & 209000 & 103000 & 3.29 \\
\hline $\begin{array}{l}\mathrm{T}_{2} \text { :Maize+Red } \\
\text { amaranth }\end{array}$ & 9.53 & 190600 & 89000 & 101600 & 2.14 \\
\hline $\mathrm{T}_{3}:$ Maize + Spinach & 9.88 & 197600 & 91000 & 106600 & 2.17 \\
\hline
\end{tabular}




\begin{tabular}{lccccc}
\hline $\mathrm{T}_{4}:$ Maize + Data & 13.11 & 262200 & 94750 & 167450 & 2.77 \\
Shak & & & & & \\
$\mathrm{T}_{5}:$ Maize + Coriander & 13.08 & 261600 & 94500 & 167100 & 2.77 \\
$\mathrm{~T}:$ Maize as sole & 8.61 & 172200 & 70000 & 102200 & 2.46 \\
\hline
\end{tabular}

Price (Tk. kg ${ }^{-1}$ ): Maize- 20.00; Potato- 12.00; Red amaranth- 8.00; Spinach- 8;

Data Shak- 12.00 and Coriander- 25.00

\section{Conclusion and Recommendation}

From these results, it revealed that maize grown as intercrop with short duration component crops (vegetables/spices) like potato, data shak and coriander may be profitable than sole maize. All of the intercrop combinations except red amaranth and spinach are agronomically and economically viable than sole cropping. The overall results indicated that among the intercrop combinations maize sowing with potato was found suitable for total productivity and economic return of inter crop systems in Sylhet region.

\section{References}

Akanda, M. E. and M. A. Quayyum. 1982. Effect of intercropping mung bean, blackgram, soybean, cowpea and groundnut with maize. Bangladesh J. Agril. Res. 7(1): 66-69.

Ali, M.R.M., S. Rahman, M. Asaduzzaman, M.M. Hossain and M.A. Mannan. 2015. Intercropping maize with different vegetables. Bangladesh Agron. J. 18(1): 4952.

Alom, M. S., N. K. Paul and M. A. Quayyum. 2008. Performance of hybrid maize (Zea mays L.) under intercropping systems with mungbean in different planting methods. SAARC J. Agri. 6:73-82.

Anjaneyulu, V. R., S. P. Singh and M. Pal. 1982. Effect of competition free period and technique and pattern of pearl millet planting on growth and yield of mungbean, and total productivity in solid pearl millet and pearl millet/mungbean intercropping system. Indian J. Agron. 27(3):219-226.

Bhuiyan, M. S., S. K. Bhowal, I. S. Farhad, M. M. U. Chowdhury, and M. Amin. 2013. Intercropping soybean with kaon in varying plant population in the coastal area of Noakhali region. Bangladesh Agron. J. 16(1): 81-86.

Dewit, C. T. and J. P. Vander Bergh, 1965. Competition between herbage plants. Neth. J. Agric. Sci. 13: 212-221.

Farhad, I. S. M. U. A. Chowdhury, S. K. Bhowal and A. S. M. M. R Khan. 2014. Chilli-garlic intercropping system in coastal saline area. App. Sci. Report. PSCI Publications. 2(2): 47-50.

Hasem, A and A. F. M. Moniruzzaman. 1986. Effect of intercropping maize with cowpea at varying plant population levels. Bangladesh J. Agron. 1: 25-39.

Hossain, M. H., S. K. Bhowal, A. S. M. M. R. Khan. 2015. Intercropping system of maize with different winter vegetables. Malays. J. Med. Biol. Res. vol. 2(2).

Mondol, M. R. I., M. R. Khan, M. A. Ali, M. N. Islam and M. A. Mannan. 1999. A study on intercropping sesame with groundnut. Bangladesh J. Agril. Res. 24(4): 657-662.

Pandey, P. R. and K. B. (eds.) Koirala. 2017. Best Practices of Maize Production Technologies in South Asia. SAARC Agriculture Centre, Dhaka: p145. 
Quayyum, M. A., M. E. Akanda and T. Islam. 1985. Effect of intercropping maize with groundnut at varying levels of plant population and nitrogen levels, Bangladesh J. Agric.10(3):1-6.

Rahaman, M. A., M. M. Rahman, S. Roy, M. Ahmed and M. S. Bhuyan. 2015. On-farm study on intercropping of hybrid maize with different short duration vegetables in the charland of Tangail. Bangladesh Agron. J. 2015, 18(2): 65-69.

Rahman, M. A. 1999. Comparative performance of intercropping in pulse and oil seeds with rainfed wheat (Triticum aestivum) in Bangladesh. Indian J. Agron. 44 (3): 504-508.

Sarker, U. K., S. Dey, S. Kundu and M. A. Awal. 2013. On-farm study on intercropping of hybrid maize with short duration vegetables. J. Bangladesh Agril. Univ. 11(1): 1-4.

Shaheb, M. R and M. I. Nazrul. 2014. Production and economics of mixed intercropping of potato with other short duration vegetables. Bangladesh Agron. J. 17(2): 39-46. 